\title{
Optoaccoustic Tomography - good news for microcirculatory research
}

\author{
Tomografia Optoacústica - boas notícias para a investigação microcirculatória
}

Tiago Granja, Sérgio Faloni de Andrade, and Luis Monteiro Rodrigues *

CBIOS_Universidade Lusófona’s Research Center for Biosciences \& Health Technologies, Campo Grande 376, 1749-024

Lisboa, Portugal

*corresponding author / autor para correspondência: monteiro.rodrigues@ulusofona.pt

\begin{abstract}
Tomographic imaging is a well established technology in preventive medicine and biomedical research, although not without limitations and concerns. Optoacoustic tomography (OAT) is a recent development that bridges optical and sonographic techniques to solve spatial resolution in deep-tissue imaging. In addition to safety advantages, OAT allows multiple wavelength readings for natural thermoelastic chromophores. In this study, we explore Multi Spectral Optoacoustic Tomography (MSOT) capacities to simultaneously acquire three independent chromophores - deoxygenated haemoglobin $(\mathrm{Hb})$, oxygenated haemoglobin $\left(\mathrm{HbO}_{2}\right)$, and melanin, from healthy human volunteers, with maximal molar extinction of $\mathrm{HbO}_{2}$ at $950 \mathrm{~nm}, \mathrm{Hb}$ at $750 \mathrm{~nm}$ and melanin at $680 \mathrm{~nm}$. Later we demonstrate how image stability during acquisition is fundamental for optimal resolution, precision and consistency of high throughout MSOT data collection. From recorded scans, a workflow is layered for data evaluation. With the MSOT dedicated software results were extracted from 3D image analysis of deep $\left(15 \mathrm{~mm}^{3}\right)$ vessels. The possibilities offered by this new system, specially in vascular pathophysiology, are immense and can be extended beyond current knowledge.
\end{abstract}

Keywords: Optoacoustic tomography; MSOT; haemoglobin; microcirculation; vascular research

\section{Resumo}

A tomografia como tecnologia de imagem está bem estabelecida na medicina preventiva e na investigação biomédica, embora com algumas limitações. A tomografia optoacústica (OAT) é um desenvolvimento recente que faz a ponte entre a óptica e a sonografia para abordar a resolução espacial em tecidos mais profundos. Além das vantagens relacionadas com a segurança, a OAT permite a leitura de comprimentos de onda múltiplos para cromóforos termo-elásticos naturais. Neste estudo, exploramos as capacidades da Tomografia Optoacústica Multiespectral (MSOT) para adquirir simultaneamente pelo menos três cromóforos independentes - Hemoglobina desoxigenada $(\mathrm{Hb})$, Hemoglobina oxigenada $\left(\mathrm{HbO}_{2}\right)$ e melanina em humanos saudáveis com extinção molar máxima de $\mathrm{HbO}_{2}$ a $950 \mathrm{~nm}, \mathrm{Hb}$ a $750 \mathrm{~nm}$ e melanina a $680 \mathrm{~nm}$. Mais tarde, demonstramos como a estabilidade da imagem durante a aquisição é fundamental para a melhor resolução, precisão e consistência da elevada produção de dados do MSOT. A partir de varrimentos gravados, o fluxo de trabalho é estratificado para avaliação de dados. O software dedicado MSOT permite a análise de imagem $3 \mathrm{D}$ de vasos profundos $\left(15 \mathrm{~mm}^{3}\right)$. As possibilidades oferecidas por este novo sistema especialmente na patofisiologia vascular são imensas e podem ser alargadas para além do conhecimento actual.

Palavras-chave: Tomografia optoacústica; MSOT; Hemoglobina; microcirculação; investigação vascular 


\section{Introduction}

The importance of tomography in preventive medicine as in biomedical research is well established. Tomographic techniques such as computed tomography (CT), single-photon emission computed tomography (SPECT), and positron emission tomography (PET) offer different image resolution and contrast, meaning also different applicabilities, costs, and limitations. (1-4). A major limitation of this technology is spatial resolution in deep-tissue imaging due to light diffusion effects $(4,5)$. Recent advances in photonics and optical imaging have drawn our attention to new optical tomography systems such as diffuse optical tomography (DOT), fluorescence molecular tomography (FMT), bioluminescence tomography (BLT), and photoacoustic tomography (PAT). These new developments aim to improve sensitivity and precision, and include new learning methods to provide more accurate and reliable reconstruction analysis $(5,6)$.

Photoacoustic tomography (PAT) is a particularly interesting imaging technology, as it combines optics and ultrasound principles rather than classical ionizing radiation. It is also known as thermoacoustic tomography (TAT) or, more currently, optoacoustic tomography (OAT). This technology uses laser light of different frequencies to heat and expand the targeted tissue, creating a sonographic wave that can be measure at skin surface (6-9). This signal can then be used to produce an image by specific reconstruction algorithms. Different biological components can be targeted by different laser wavelengths. Compared with similar technologies, several advantages of this technique can be identified. PAT does not use ionizing radiation, in contrast to classical CT PET and or MRI, and is faster, easier, and less expensive to operate. Compared with DOT or with FMT, PAT shows better penetration capacities with high resolution, showing better contrast and fewer artifacts than sonography (6-10), the most common technology for cardiovascular diagnostics $(9,10)$

PAT applications have expanded significantly in the last years, from basic investigation to clinical applications, also in cardiovascular medicine (10-13). A recent development of this technology is the use of lasers with multiple wavelengths - the multi-spectral optoacoustic tomography (MSOT) - which allows the (in vivo) identification of several chromophores without contrast agents. These chromophores might be regarded as endogenous biomarkers of microcirculatory function, such as oxygenated haemoglobin $\left(\mathrm{HbO}_{2}\right)$, deoxygenated

\section{Introdução}

A importância da tomografia na medicina preventiva assim como na investigação biomédica está bem estabelecida. As técnicas de tomografia como a tomografia computorizada (CT) de fotão único (SPECT) e a tomografia por emissão de positrões (PET) oferecem diferentes resoluções de imagem e contraste, o que significa também diferentes aplicabilidades e custos. (1-4). Uma limitação desta tecnologia é a resolução espacial das imagens em tecidos profundos devido à difusão de luz $(4,5)$. Avanços recentes em fotónica e imagem óptica chamam a nossa atenção para novos sistemas de tomografia óptica como a tomografia óptica difusa (DOT), a tomografia molecular fluorescente (FMT), a tomografia de bioluminescência (BLT), e a tomografia fotoacústica (PAT). Todos estes novos desenvolvimentos visam melhorar a sensibilidade e precisão, o que inclui a utilização de novos métodos de aprendizagem que proporcionam uma melhor e mais fiável análise de reconstrução $(5,6)$.

A tomografia fotoacústica (PAT) é uma tecnologia de imagem que parece ser particularmente interessante, uma vez que combina princípios ópticos e de ultrasonografia em alternativa á radiação ionizante clássica. É também conhecida como tomografia termoacústica (TAT) ou mais actualmente tomografia optoacústica (OAT). Esta tecnologia utiliza uma luz laser de diferentes frequências que aquece e expande o tecido alvo, criando uma onda sonográfica que pode ser medida à superfície da pele (6-9). Este sinal pode agora ser utilizado para produzir uma imagem através de algoritmos específicos de reconstrução. Um laser com compromentos de onda é utilizado para medir diferentes componentes biológicos. Em comparação com tecnologias semelhantes, várias vantagens podem ser identificadas. Pensando na clássica CT , PET e mesmo na RM, o PAT não utiliza radiação ionizante, é mais rápido, fácil de operar e menos dispendioso. Em comparação com o DOT ou com o FMT, o PAT mostra melhores capacidades de penetração com alta resolução, mostrando melhor contraste e menos artefactos do que a Sonografia (6-10) a tecnologia mais popular utilizada no diagnóstico cardiovascular $(9,10)$.

As aplicações PAT expandiram significativamente nos últimos anos, desde a investigação básica até aplicações clínicas, também na medicina cardiovascular (1013). Um desenvolvimento recente desta tecnologia - a tomografia optoacústica multiespectral (MSOT) fornece lasers com comprimentos de onda múltiplos que permitem identificar vários cromóforos sem 
Table 1 - Characterization of the study population. bpm - beats per minute.

Tabela 1 - Caracterização da população em estudo. bpm - batimentos por minuto

\begin{tabular}{r|rrrr} 
& Men / Homens & Women / Mulheres \\
\hline Age/ Idade & 3 & & 3 & \\
(years old / anos idade) & 43.50 & \pm 1.00 & 29.89 & \pm 14.66 \\
Height/ Altura (m) & 1.75 & \pm 0.07 & 1.71 & \pm 0.03 \\
Weight / Peso (kg) & 76.00 & \pm 6.08 & 71.50 & \pm 0.71 \\
BMI (kg/m $\left.{ }^{2}\right)$ & 24.79 & \pm 0.17 & 24.46 & \pm 0.57 \\
Heart Rate / & 70.50 & \pm 4.20 & 73.67 & \pm 5.98 \\
Frequência Cardíaca (bpm) & & & & \\
Systolic Pressure / & 123.50 & \pm 9.43 & 113.73 & \pm 8.11 \\
Pressão Sistólica (mmHg) & & & & \\
Diastolic Pressure / & 85.00 & \pm 9.43 & 77.91 & \pm 9.08 \\
\hline Pressão Diastólica (mmHg) & & & &
\end{tabular}

haemoglobin $(\mathrm{Hb})$, or the mean saturation of oxygen $\left(\mathrm{mSO}_{2}\right)$ (14-18). Other chromophores, including lipids, melanin and water might also be detected and visualised for functional analysis $(10,16)$. In the present study we explore the operation and capabilities of MSOT in a set of healthy human participants.

\section{Materials and Methods}

\section{Participants}

Our convenience sample included six healthy participants of both genders ( 3 men and 3 women), 18 to 60 years old (mean \pm sd $36.70 \pm 15.16$ ), selected following specific inclusion / non-inclusion criteria. Participants were normotensive, nonsmokers, and free of any medication or food supplementation. Restrictions included caffeine and alcohol consumption 24 hours prior to measurements, and the use any topical formulations (including cosmetic) on the skin. Participants reported regular physical activity and absence of any metabolic disease (diabetes, dyslipidaemia). Table 1 summarises the full characterization of the participants. All study procedures followed the principles established by the Helsinki Declaration and subsequent amendments (19) and were previously approved by the Institutional Ethics Committee. agentes de contraste. Estes cromóforos podem ser considerados como biomarcadores endógenos de função microcirculatória, tais como hemoglobina oxigenada $\left(\mathrm{HbO}_{2}\right)$, hemoglobina desoxigenada $(\mathrm{Hb})$, ou a saturação média de oxigénio $\left(\mathrm{mSO}_{2}\right)(14-18)$. Outros cromóforos como os lípidos, melanina e água podem também ser detectados e visualizados para análise funcional $(10,16)$. No presente estudo exploramos o funcionamento e as capacidades do MSOT num conjunto de participantes humanos saudáveis.

\section{Materiais e Métodos}

\section{Participantes}

Esta amostra de conveniência envolveu seis participantes saudáveis de ambos os sexos ( 3 homens e 3 mulheres), de 18 a 60 anos (média + dp 36,70 $\pm 15,16$ ) seleccionados segundo critérios específicos de inclusão / não-inclusão. Os participantes eram normotensos, não fumadores, e livres de qualquer medicação ou suplemento alimentar. As restrições incluíam o consumo de cafeína e álcool 24 horas antes das medições, e a utilização de quaisquer formulações tópicas (incluindo cosméticas) sobre a pele. Os participantes relataram actividade física regular e ausência de qualquer doença metabólica (diabetes, dislipidemia). A Tabela 1 resumes a caracterização completa dos participantes. Todos os procedimentos seguiram os princípios estabelecidos pela Declaração de Helsínquia e subsequentes emendas (19) e foram previamente aprovados pela Comissão de Ética Institucional. 
Multi Spectra Optoacoustic Tomography and Image Analysis

A MSOT optoacoustic imaging system from Acuity (iThera Medical $\mathrm{GmbH}$, Munich, Germany) was used for all analyses. This instrument is composed of a Nd:YAG laser, which produces excitation pulses of $9 \mathrm{~ns}$ at wavelengths from $680 \mathrm{~nm}$ to $980 \mathrm{~nm}$. The MSOT system repetition rate can reach $50 \mathrm{~Hz}$ with a wavelength tuning speed of $10 \mathrm{~ms}$ and a peak pulse energy of $35 \mathrm{~mJ}$ at $730 \mathrm{~nm}$. A fiber-optic bundle integrated into the detector produces a circular spot of light of approximately $10 \mathrm{~mm}$ diameter. In this system, ultrasound detection is made by 256 ultrasound transducers with a centre frequency of $8 \mathrm{MHz}(60 \%$ bandwidth), organized in a hemispherical array of $98^{\circ}$ angular coverage and a radius of curvature of 30 $\mathrm{mm}$. The laser light is conducted to a $3 \mathrm{D}$ probe by an optical fiber of $15 \mathrm{~mm}^{3}$. After scanning, images were processed for fluence correction, optical focusing given by the speed of sound and optoacoustic thermoelastic signals of the selected chromophores for $\mathrm{Hb}$ and $\mathrm{HbO}_{2}$ were reconstructed, and Regions of Interest (ROIs) were analysed with the iThera Medical ViewMSOT software.

ImageJ software (National Institutes of Health, USA v.1.53k14 from 26 June 2021) was used to analyse the merged, (re)constructed, image from individual images of $\mathrm{X}, \mathrm{Y}$ and $\mathrm{Z}$ axis scans.

\section{Experimental Procedure}

The ventral aspect of a randomly chosen forearm, with body hair chemically removed immediately prior to analysis, was marked for probe application $(4,20)$. The MSOT 3D probe was then applied and focused in a fixed orientation. A thin layer of gel for sonography was applied in the MSOT 3D cup before contact with the skin to improve image acquisition conditions. The MSOT 3D cup was locked in position with a self-assembled arm (ITEM - Engineering,Solingen ,Germany)(Figure 1).

\section{Statistics}

Statistical analysis was performed with GraphPad Prism 9.2.0, MachineID: 0861F12DB8D10, and normal distribution was tested with the Shapiro-Wilk test and direct observation of QQ plots. Except where noted, all data is presented as mean \pm sd. Significance was observed through $t$ test of selected comparisons, analysed with $95 \%$ confidence level.
Tomografia Optoacústica Multi-Espectral e Análise de Imagem

Foi utilizado um sistema de imagem optoacústica MSOT da Acuity (iThera Medical GmbH, Munique, Alemanha). Este instrumento é composto por um laser $\mathrm{Nd}$ :YAG que fornece impulsos de excitação de $9 \mathrm{~ns}$ em comprimentos de onda de $680 \mathrm{~nm}$ a $980 \mathrm{~nm}$. A taxa de repetição do sistema MSOT vai até $50 \mathrm{~Hz}$ com uma velocidade de afinação do comprimento de onda de 10 ms e uma energia de pico de pulso de $35 \mathrm{~mJ}$ a $730 \mathrm{~nm}$. Um feixe de fibras integrado no detector fornece uma mancha de luz circular de aproximadamente $10 \mathrm{~mm}$ de diâmetro. A detecção ultra-sónica iThera MSOT é composta por 256 transdutores ultra-sónicos com uma frequência central de $8 \mathrm{MHz}$ (60\% de largura de banda), organizados numa matriz hemisférica de 98 graus de cobertura angular e um raio de curvatura de $30 \mathrm{~mm}$. A luz laser é conduzida a uma sonda 3D por fibra óptica com $15 \mathrm{~mm}^{3}$. Após a digitalização, as imagens foram processadas para correcção da fluência, a focagem óptica dada pela velocidade do som e os sinais termoelásticos optoacústicos de cromóforos seleccionados $\mathrm{Hb}, \mathrm{HbO}_{2}$ foram reconstruídos e a Região de Interesse (ROI) analisada com o software iThera Medical ViewMSOT.

O software ImageJ (National Institutes of Health, USA v.1.53k14 de 26 de Junho de 2021) foi utilizado para trabalhar com imagens reconstruídas a partir de imagens individuais de varrimentos dos eixos $\mathrm{X}, \mathrm{Y}$ e Z

\section{Procedimento experimental}

Oaspecto ventral do antebraço, escolhido aleatoriamente em cada participante, foi previamente tratado com a remoção química do pêlo corporal, e marcado para aplicação da sonda $(4,20)$. Em seguida, a sonda MSOT 3D foi aplicada e focalizada numa orientação fixa. Uma fina camada de gel para sonografia foi aplicada no detector 3D do MSOT antes do contacto com a pele para proporcionar melhores condições de aquisição de imagem. O detector 3D do MSOT foi bloqueado na posição com um braço desenhado com a tecnologia da ITEM - Engeneering (Solingen, Alemanha) (Figura 1).

\section{Estatística}

A análise estatística foi realizada com o GraphPad Prism 9.2.0, MachineID: 0861F12DB8D10, e a distribuição da normalidade testada com o Shapiro-Wilk e a observação directa das parcelas QQ. Todos os dados são apresentados como média $\pm d p$, excepto quando indicados de forma diferente. A significância foi observada através do teste $\mathrm{t}$ de comparações seleccionadas analisadas com $95 \%$ do nível de confiança. 


\section{Results and Discussion}

The MSOT detects numerous chromophore signals at a repetition rate of $50 \mathrm{~Hz}$ with a wavelength tuning speed of $10 \mathrm{~ms}$. MSOT wavelengths range from near visible to infra-red imaging (680 to $980 \mathrm{~nm}$ ), allowing non-invasive analysis up to $15 \mathrm{~mm}$ deep and producing regions of analysis of $15 \mathrm{~mm}^{3}$ from the recording of 10 frames (in 2 seconds) for each (X, Y and Z) axis for every (preset) thermoelastic chromophore. Micrometre resolution of selected regions yield $\mathrm{HbO}_{2}, \mathrm{Hb}$, and melanin data from 3D reconstructed images (using a single-element ultrasonic transducer and a curved ultrasound 2-D sensor), referred as the most important biomarkers from OAT $(4,15,18,21,22)$.

The MSOT can virtually be instructed to "unmix" up to three different thermoelastic chromophores (certified by the manufacturer) and loaded as pre-sets before any

\section{Resultados e Discussão}

O MSOT detecta vários cromóforos a uma taxa de repetição de $50 \mathrm{~Hz}$ com uma velocidade de afinação do comprimento de onda de $10 \mathrm{~ms}$. Os comprimentos de onda MSOT variam desde o visível ao infravermelho (680 a 980 nm) permitindo abordar, demodo não invasivo uma grande profundidade (até $15 \mathrm{~mm}$ ) em 2 segundos. A resolução microscópica das regiões seleccionadas produz dados de $\mathrm{HbO}_{2}, \mathrm{Hb}$ desoxigenada e melanina de imagens reconstruídas em 3D (utilizando um transdutor ultra-sónico de um único elemento e um sensor de ultrasons curvo 2-D) referidos como os biomarcadores mais importantes da PAT $(4,15,18,21,22)$.

As imagens adquiridas pelo MSOT correspondem a $15 \mathrm{~mm}^{3}$ em volume. Para cada varrimento, o sistema regista 10 frames para cada eixo $\mathrm{X}, \mathrm{Y}$ e $\mathrm{Z}$ para cada cromóforo termoelástico produzindo um sinal entre

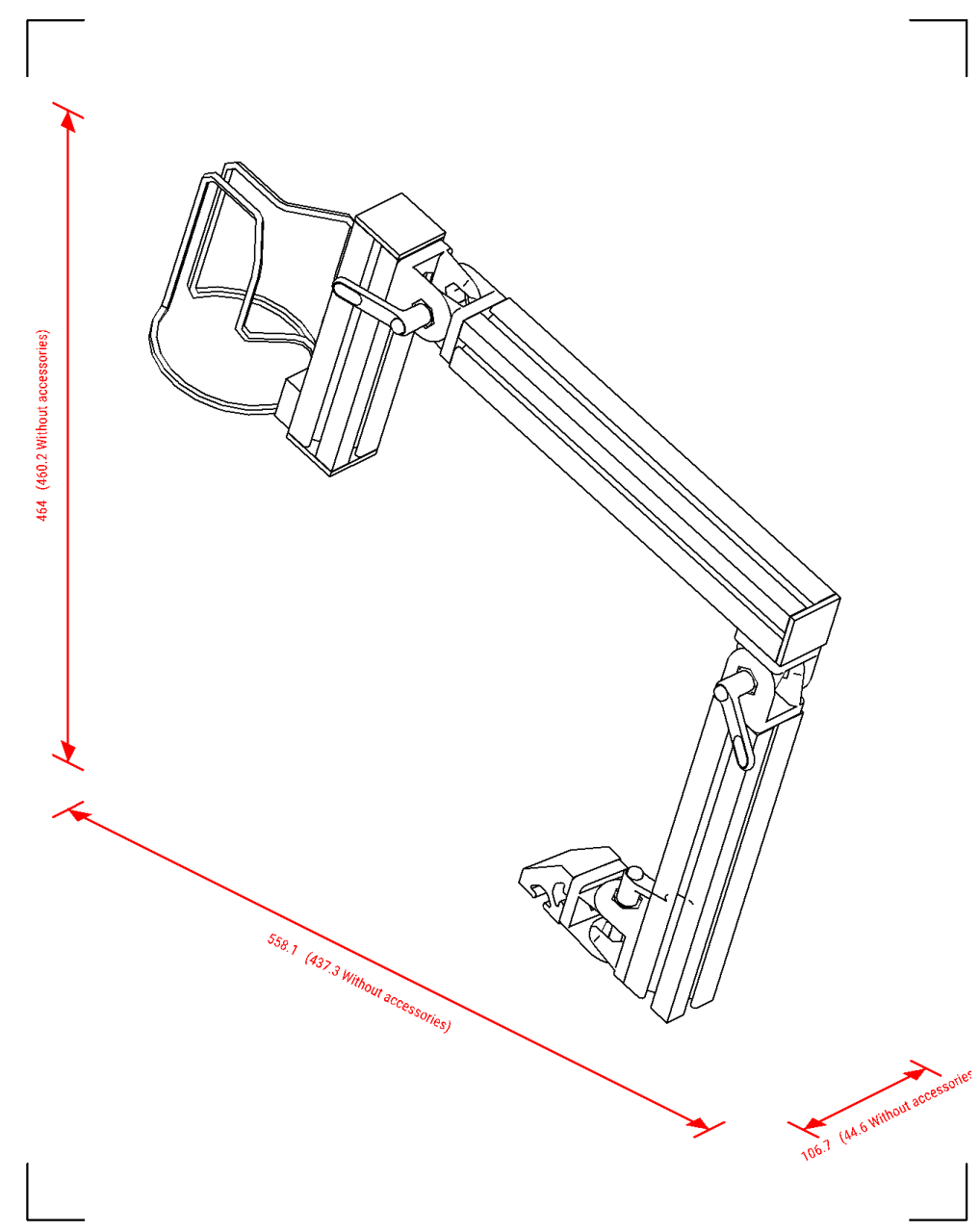

Figure 1 - Isometric view of the MSOT probe holder flexible arm. Designed to hold the MSOT 3D probe this piece was designed with the ITEM engineering tool (https://item.engineering/).

Figura 1 - Vista isométrica do braço flexível que suporta a sonda MSOT. Concebida para estabilizar a sonda MSOT 3D esta peça foi construida com a ferramenta de engenharia ITEM (https://item.engineering/). 
acquisition. As discussed, for our study, the instrument was set up to observe signals from $\mathrm{HbO}_{2}, \mathrm{Hb}$, and melanin. While acquiring from any given region (e.g., the skin), an image stack composed of XY, XZ, and YZ axes is generated (Figure 2A). At a depth of $15 \mathrm{~mm}$, the images produced have a resolution of $150 \mu \mathrm{m}$, enabling the identification of the first and second vascular plexuses of the skin.

\section{Spectra unmixing and image merge}

Objects generated during acquisition are three dimensional (3D), and the screenshot view allows measurements and annotations as shown in Figure 2B. To extract data from acquired images, prior analysis requires assembly of multiple thermoelastic signals and post processing by the iThera MSOTview software. This process follows a reconstruction sequence of optoacoustic signals - the correction of the speed of
680 a $980 \mathrm{~nm}(4,14,18,22)$. O MSOT pode virtualmente ser instruído para distinguir até três cromóforos termoelásticos diferentes certificados pela empresa iThera e carregados como programa de função antes de qualquer aquisição. Para o ensaio actual, a configuração carregada foi orientada para observar sinais de $\mathrm{HbO}_{2}$, $\mathrm{Hb}$ e melanina respectivamente. Enquanto se adquire sinal em qualquer região (por exemplo, a pele), é gerado um conjunto de imagens compostas pelos eixos $\mathrm{XY}, \mathrm{XZ}$, e YZ (Figura 2A). A $15 \mathrm{~mm}$ de profundidade, as imagens têm uma resolução de $150 \mu \mathrm{m}$, permitindo a identificação do primeiro e segundo plexos vasculares da pele (Figura 2B).

\section{Resolução espectral e construção de imagens}

Os objectos gerados durante a aquisição são tridimensionais (3D), e a vista de ecrã permite medições e anotações como mostra a Figura 2B. Para extrair dados das imagens adquiridas, a análise prévia requer a montagem de múltiplos sinais termoelásticos e o pós-processamento pelo software iThera MSOTview. Este processo segue uma sequência de reconstrução

A

B

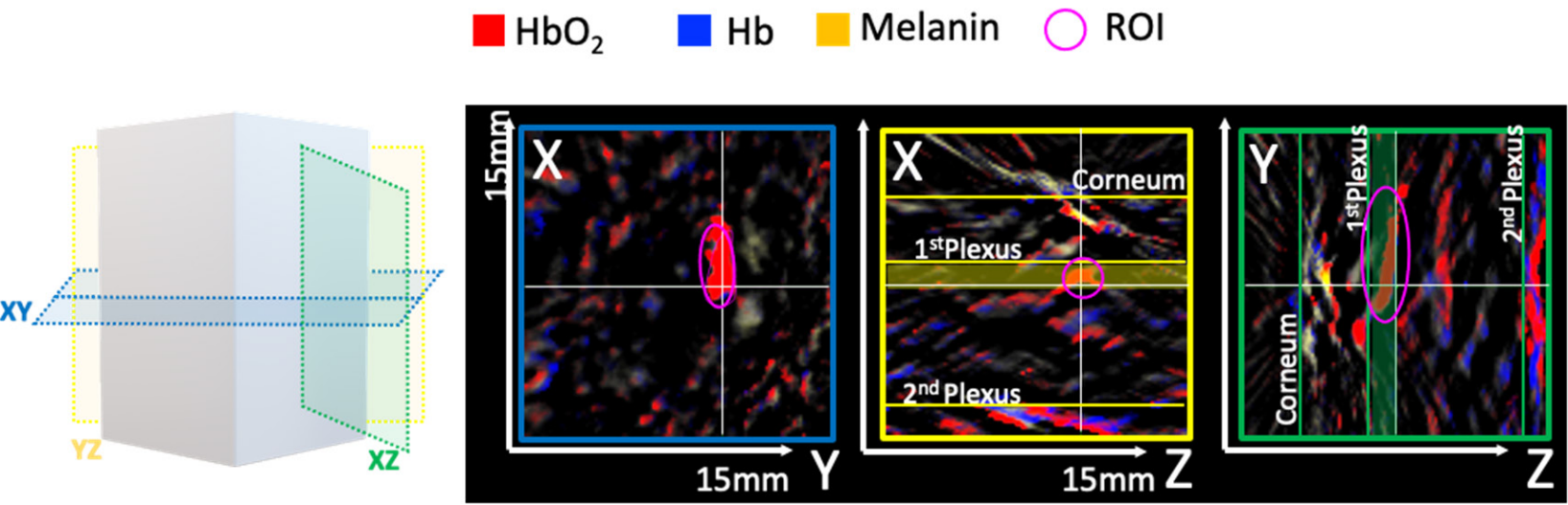

Figure 2 - MSOT image acquisition overview.

Image of $\mathrm{HbO}_{2}$ acquired signal displayed in red, $\mathrm{Hb}$ signal displayed in blue, and melanin signal displayed in yellow. A) Graphical representation of acquired images in 3D with superimposed axis XY (blue plane), $\mathrm{XZ}$ (green plane) and YZ (yellow plane). Selected region of interest (ROI) for analysis are shown in magenta. B) Dissection of skin structure through all information given by MSOT chromophores $\mathrm{HbO}_{2}, \mathrm{Hb}$ and melanin displayed with a tissue depth of $15 \mathrm{~mm}$ in three dimensions XY (blue plane), XZ (green plane) and YZ (yellow plane).

Figura 2 - Visão geral da aquisição de imagens com o MSOT.

Imagem do sinal adquirido de $\mathrm{HbO}_{2}$ em vermelho, sinal de $\mathrm{Hb}$ em azul e sinal de melanina em amarelo. A) Representação gráfica das imagens adquiridas em 3D com sobreposição dos eixos XY (plano azul), XZ (plano verde) e YZ (plano amarelo). Qualquer região de interesse (ROI) seleccionada para análise será mostrada em magenta. B) Dissecção da estrutura da pele através de toda a informação MSOT fornecida pelos cromóforos $\mathrm{HbO}_{2}, \mathrm{Hb}$ e melanina apresentados com uma profundidade de tecido de $15 \mathrm{~mm}$ em três dimensões XY (plano azul), XZ (plano verde) e YZ (plano amarelo). 


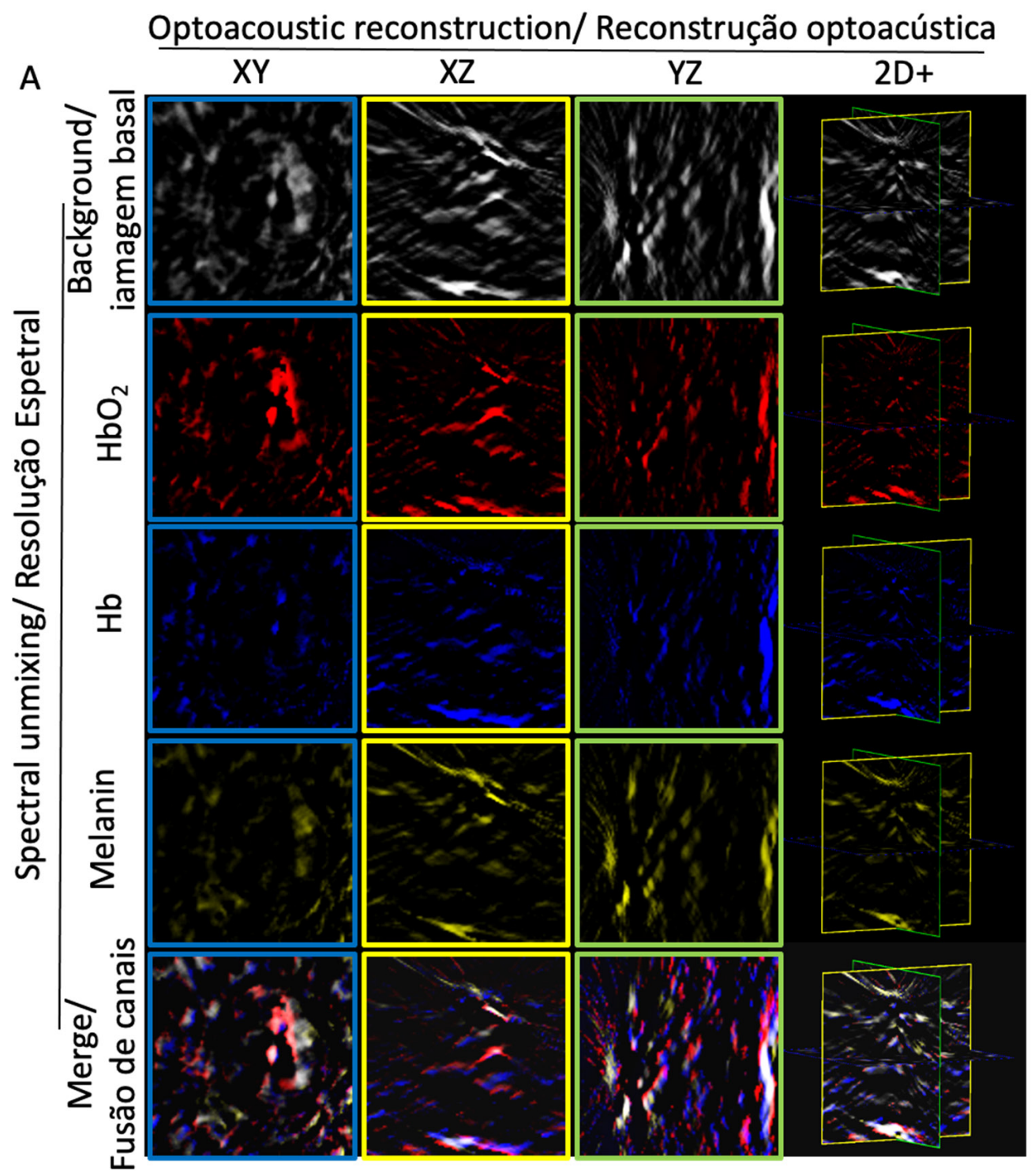

B

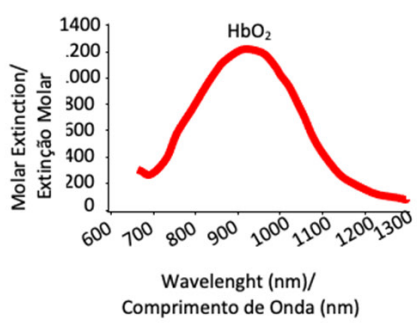

C

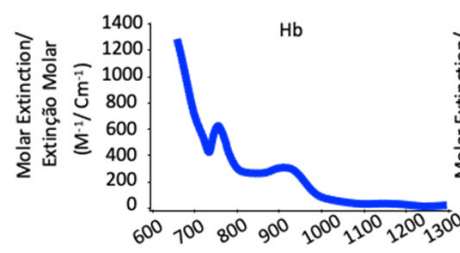

Wavelenght $(\mathrm{nm}) /$ Comprimento de Onda (nm)
D

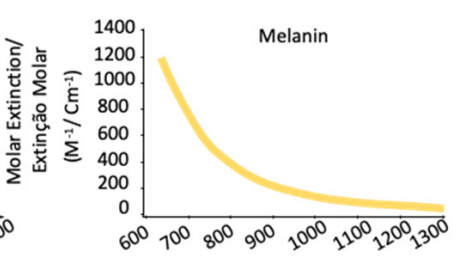

Wavelenght (nm)/ Comprimento de Onda (nm)

Figure 3 - Spectra of molar extinction of natural chromophores $\mathrm{HbO}_{2}, \mathrm{Hb}$ and melanin and the 2D+ display of optoacoustic signals isolated and merged after post processing analysis.

A) Representative single images of unmixed acquired signals by the MSOT, resulting merge scans and 2D+ view. B) for best signal acquisition MSOT is set to reads maximal $\mathrm{HbO}_{2}$ molar extinction at $950 \mathrm{~nm}$; $\mathrm{C}$ ) $\mathrm{Hb}$ molar extinction is collected at $750 \mathrm{~nm}$ and D) melanin molar extinction given at $680 \mathrm{~nm}$.

Figura 3 - Espectros de extinção molar de cromóforos naturais $\mathrm{HbO}_{2}, \mathrm{Hb}$ e melanina e a visualização 2D+ de sinais optoacústicos isolados e fundidos após análise pós processamento. A) Imagens únicas representativas dos sinais adquiridos não misturados pelo MSOT, resultantes das varreduras de fusão e visualização 2D+. B) para melhorar a aquisição de sinais, o MSOT está definido para ler a extinção molar máxima de $\mathrm{HbO}_{2}$ a $950 \mathrm{~nm}$; C) A extinção molar de $\mathrm{Hb}$ é recolhida a $750 \mathrm{~nm}$ e D) a extinção molar de melanina dada a $680 \mathrm{~nm}$. 
sound for calibration of best focus, application of fluence correction, and calculation of spectral unmixing for the acquired signals of $\mathrm{HbO}_{2}, \mathrm{Hb}$ and melanin (Figure $3 \mathrm{~A}$ ). For best signal acquisition, the MSOT reads maximal $\mathrm{HbO}_{2}$ molar extinction at $950 \mathrm{~nm}, \mathrm{Hb}$ at $750 \mathrm{~nm}$, and melanin at $680 \mathrm{~nm}$ (Figure 3B-D). Representative images of each of the acquired signals of $\mathrm{HbO}_{2}, \mathrm{Hb}$, and melanin demonstrate the perfect unmixing of the acquired signals in all $\mathrm{XY}, \mathrm{XZ}$, and $\mathrm{YZ}$ axes and the plot of the respective merged image (Figure 3A). Additionally, a 2D+ image view is generated for optimal navigation over the 3D images acquired and to adjust proper colour intensities. Single chromophore images are fundamental to set correct colour lookup tables and to enable independent study of the acquired signals.

\section{Optoaccoustic reconstruction and Region of Interest (ROI) analysis}

After image reconstruction, fluence correction, focusing of speed of sound, unmixing, and adjustment of color balance and saturation of preferred lookup tables, each chromophore signal acquired by the MSOT can be analysed. To overcome signal flattening from signal-tonoise ratio derived from large image analysis, elements of each 3D scan must be selected as Regions-Of-Interest (ROI) before data analysis. ROI analysis (depicted in Figure 4A) follows a microvasculature ROI structure in 9 of all 10 frames acquired. Each frame is of 150 $\mu \mathrm{m}$ of tissue depth in $\mathrm{X}, \mathrm{Y}$ and $\mathrm{Z}$ axes. To acquire data from any ROI, each frame must follow the selected ROI across XZ (yellow bar in depicted fames) and YZ (green bar in depicted frames) while a polygon selection tool (magenta selected area) delineates the ROI in XY (blue frames). On the 2D+ image overview, the 3D area of analysis is built (Figure 4A).

\section{Biomarkers}

Through the MSOTview each scanned ROI exported data is provided in bursts of ten images derived from optoacoustic reconstruction. ROI selection of MSOT acquired images allows calculation of ROI volume $\left(\mathrm{mm}^{3}\right)$, as well as the concentrations of $\mathrm{HbO}_{2}$ (in arbitrary units a.u.), oxidized $\mathrm{Hb}$ (a.u.) and melanin (a.u.) $(4,14,18,20)$.

Overall, the acquisition speed of ten images of three chromophores over a reconstruction of sixse wavelengths $(700 \mathrm{~nm}, 730 \mathrm{~nm}, 760 \mathrm{~nm}, 800 \mathrm{~nm}, 850$ $\mathrm{nm}$, and $900 \mathrm{~nm}$ ) is constant at $2 \mathrm{~s}$. The data stability from the selected analysed ROI is depicted by the linearity of the signal recorded for $\mathrm{HbO}_{2}$, deoxygenated $\mathrm{Hb}$, and melanin (a.u.) (Figure 4B-D). From $\mathrm{HbO}_{2}$ and de sinais optoacústicos - a correcção da velocidade do som para calibração do melhor foco, aplicação de correcção de fluência, e cálculo de resolução espectral para os sinais adquiridos de $\mathrm{HbO}_{2}, \mathrm{Hb}$ e melanina (Figura 3A). Para melhor aquisição de sinais, o MSOT lê a extinção molar máxima de $\mathrm{HbO}_{2}$ a $950 \mathrm{~nm}, \mathrm{Hb}$ a $750 \mathrm{~nm}$ e melanina a $680 \mathrm{~nm}$ (Figura 3B-D). Imagens representativas de cada um dos sinais adquiridos de $\mathrm{HbO}_{2}, \mathrm{Hb}$ e melanina demonstram a perfeita resolução dos sinais adquiridos em todos os eixos $\mathrm{XY}, \mathrm{XZ}$, e $\mathrm{YZ}$ e a montagem da respectiva imagem fundida (Figura $3 \mathrm{~A}$ ). Além disso, é gerada uma vista de imagem 2D+ para melhor navegação sobre as imagens $3 \mathrm{D}$ adquiridas e para ajustar adequadamente as intensidades de cor. As imagens monocromáticas são fundamentais para definir tabelas correctas de procura de cores e para estudar os sinais adquiridos de forma independente.

\section{Reconstrução opto-acústica e análise da Região de} Interesse (ROI)

Após reconstrução da imagem, correcção da fluência, ajuste da velocidade do som, resolução espectral, ajuste do equilíbrio da cor e saturação das tabelas de pesquisa preferidas, cada sinal cromóforo adquirido pelo MSOT pode ser analisado. Para superar o achatamento do sinal a partir da relação sinal-ruído resultante da análise de grandes imagens, os elementos de cada varrimento 3D têm de ser seleccionados como Regiões-deInteresse (ROI) antes da análise dos dados. A análise ROI (representada na Figura 4A) segue a estrutura da microvasculatura em 9 de todos os 10 fotogramas adquiridos. Cada plano é de $150 \mu \mathrm{m}$ de profundidade de tecido nos eixos X, Y eZ. Para adquirir dados de qualquer ROI, cada plano deve seguir o ROI seleccionado através de XZ (barra amarela em quadros representados) e YZ (barra verde em quadros representados) enquanto que uma ferramenta de selecção de polígono (área seleccionada magenta) delineia o ROI em XY (quadros azuis). Na visão geral da imagem $2 \mathrm{D}+$, a área de análise 3D é construída (Figura 4A).

\section{Biomarcadores}

Através do MSOTview cada dado digitalizado de cada ROI exportado é fornecido em grupos de dez imagens resultantes da reconstrução optoacústica. A selecção do ROI das imagens MSOT adquiridas permite o cálculo do volume de ROI $\left(\mathrm{mm}^{3}\right)$, concentração de $\mathrm{HbO}_{2}$ (em unidades arbitrárias a.u.), $\mathrm{Hb}$ desoxigenada (a.u.) e melanina (a.u.) $(4,14,18,20)$.

Globalmente, a velocidade de aquisição de 10 imagens de 3 cromóforos sobre uma reconstrução de 6 comprimentos 


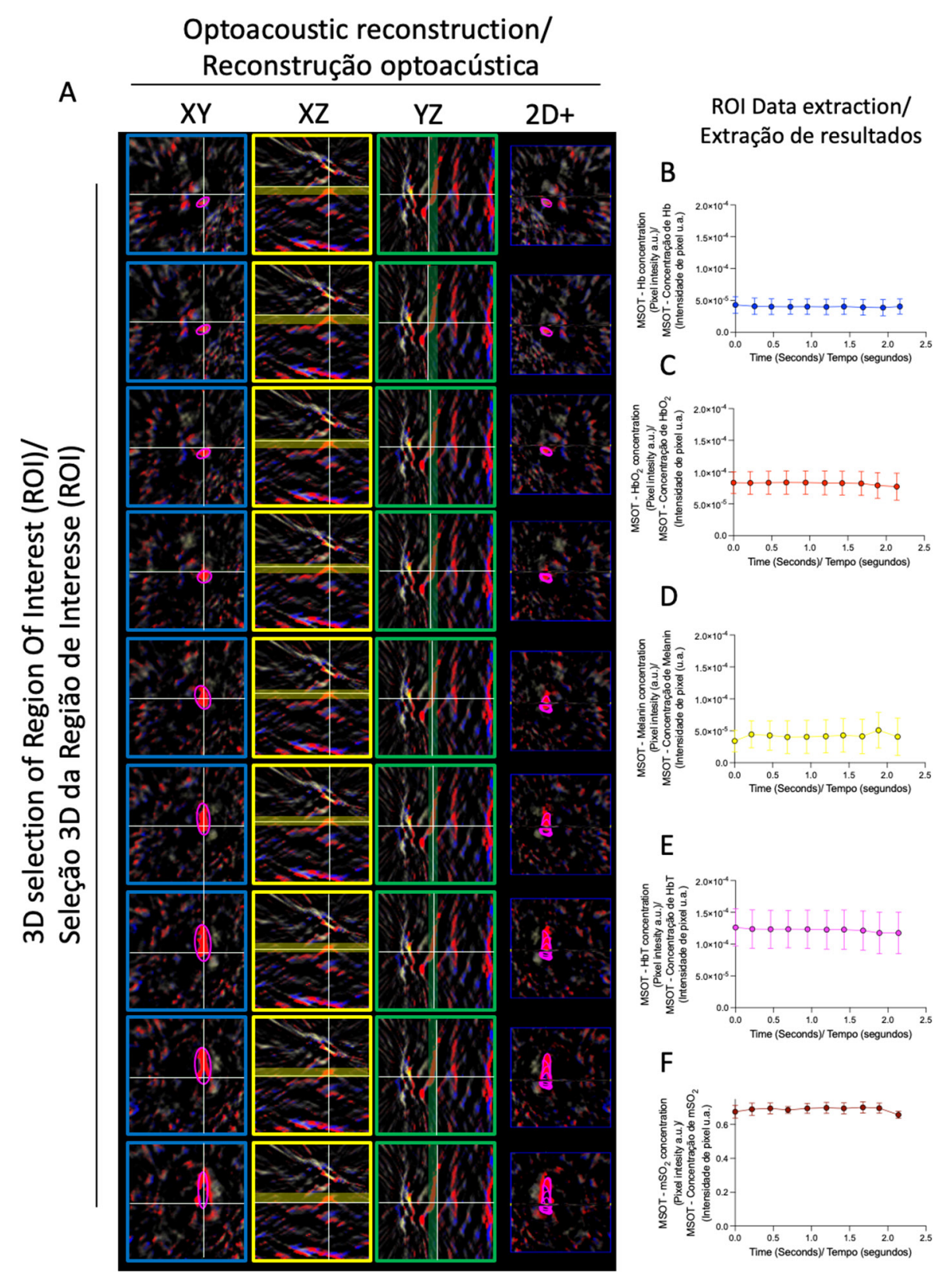

Figure 4 - ROI selection on merged scans after images post-processing.

A) Microvasculature ROI structure is present in all acquired frames. Each frame has $150 \mu \mathrm{m}$ in depth over X, Y and $\mathrm{Z}$ axis. To each frame point in $\mathrm{XZ}$ (yellow bar) and $\mathrm{YZ}$ (green bar) a polygon selection of the desired ROI is followed in XY (magenta polygon) on blue frames. In the 2D+ column is possible to observe the layering build of the 3D area of analysis. B) Data extraction from a selected Region of Interest (ROI) for hemoglobin Hb over 10 acquisition frames, C) ROI readout of $\mathrm{HbO}_{2}$, D) ROI data acquisition of melanin, E) ROI calculation of total hemoglobin $\mathrm{HbT}$ over ten collected images, F) ROI calculation of oxygen saturation $\mathrm{mSO}_{2}$.

Figura 4 - Selecção do ROI em varrimentos fundidos após pós-processamento de imagens.

A) A estrutura microcirculatória da ROI está presente em todos os planos de imagem adquiridos. Cada plano tem $150 \mu \mathrm{m}$ de profundidade nos eixos X, Y e Z. Para cada ponto em XZ (barra amarela) e YZ (barra verde), uma selecção poligonal do ROI seleccionado é seguida em XY (polígono magenta) sobre planos azuis. Na coluna 2D+ é possível observar a construção em camadas da área de análise 3D. B) Extracção de dados de uma região de interesse seleccionada (ROI) para hemoglobina $\mathrm{Hb}$ sobre 10 planos de aquisição, C) Leitura do ROI de $\mathrm{HbO}_{2}$, D) Aquisição de dados ROI de melanina, E) Cálculo do ROI da hemoglobina total HbT em dez imagens recolhidas, F) Cálculo do ROI da saturação de oxigénio $\mathrm{mSO}_{2}$. 
Table 2 - Descriptive statistics of acquired data from the MSOT selected ROI (see text). Data from HbT extracted from the MSOT in a.u. equals the addition of acquired $\mathrm{HbO}_{2}$ and $\mathrm{Hb}$ optoacoustic signals. a.u. -arbitrary units

Tabela 2- Estatística descritiva dos dados adquirido com o MSOT nas ROI selecionadas (ver texto). Os valores de $\mathrm{HbT}$ obtidos do MSOT correspondem á soma dos valores de $\mathrm{HbO}_{2}$ e $\mathrm{Hb}$ adquiridos dos sinais optoacústicos. a.u. - unidades arbitrárias

\begin{tabular}{r|ccc} 
& HbT (a.u.) & $\mathbf{H b O}_{\mathbf{2}}$ (a.u.) & $\mathrm{Hb}$ (a.u.) \\
\hline $\begin{array}{r}\text { number of entries / } \\
\text { número de entradas } \\
\text { median / }\end{array}$ & 10 & 10 & 10 \\
$\begin{array}{r}\text { mediana } \\
\text { standard deviation / } \\
\text { desvio padrão }\end{array}$ & $\mathbf{1 . 2 3 \mathrm { E } - 0 4}$ & $\mathbf{8 . 3 1 \mathrm { E } - 0 5}$ & $\mathbf{4 . 0 0 \mathrm { E } - 0 5}$ \\
\hline
\end{tabular}

A

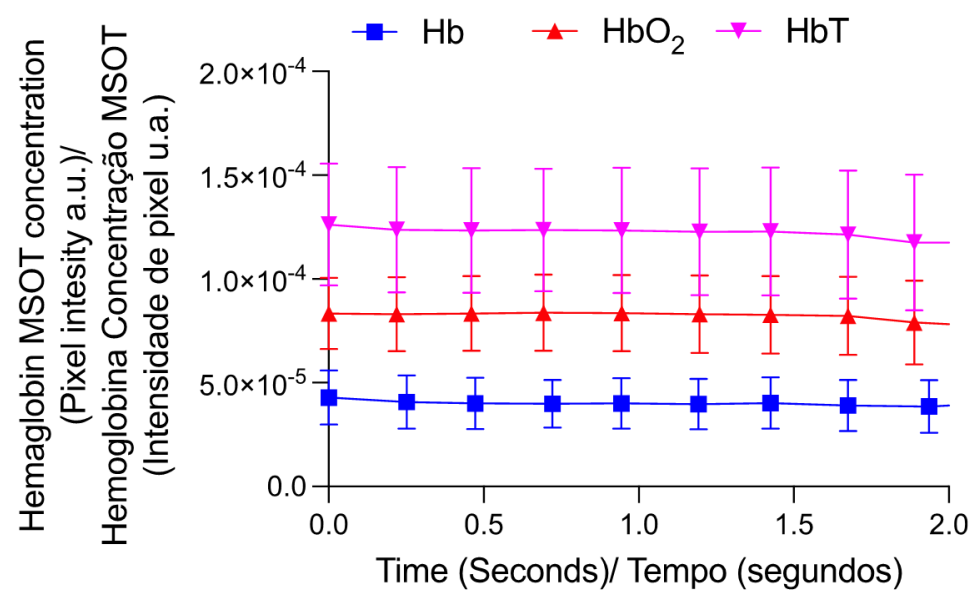

B

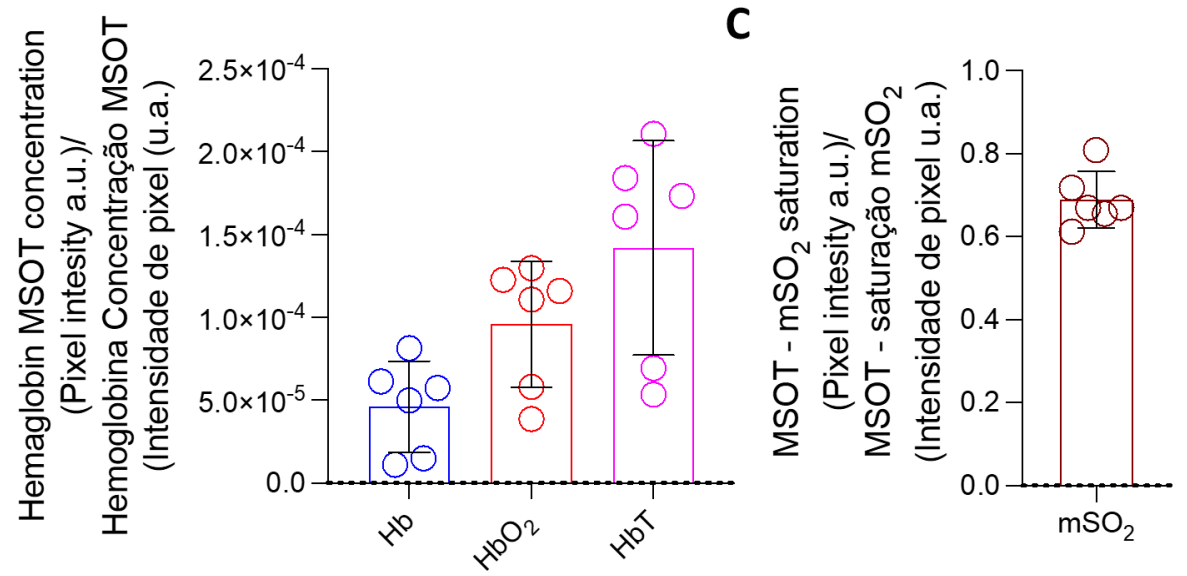

Figure 5 - Hemodynamic parameters $\mathrm{Hb}, \mathrm{HbO}_{2}$ and $\mathrm{HbT}$ acquired from a population of six volunteers.

A) Representative graphic over single MSOT readouts $(n=10)$ of hemoglobin oxygenation on ROI data of 6 participants with data distribution (mean and SD) over each reading of the equipment on a single scan, demonstrating its acquisition consistency. B) Whole blood haemoglobin concentration of $\mathrm{Hb}$ (blue), $\mathrm{HbO}_{2}$ (red) and $\mathrm{HbT}$ (pink) as arbitrary units (a.u.) at a given ROI. C) Mean oxygen saturation $\left(\mathrm{mSO}_{2}\right)$ readout above 0.7 in all volunteers in rest.

Figura 5 - Parâmetros hemodinâmicos $\mathrm{Hb}, \mathrm{HbO}_{2}$ e $\mathrm{HbT}$ adquiridos a uma população de seis voluntários.

A) Gráfico representativo de leituras únicas de MSOT $(n=10)$ de oxigenação da hemoglobina sobre dados ROI de 6 participantes com distribuição de dados (média e dp) sobre cada leitura do equipamento num único varrimento, demonstrando a sua consistência de aquisição. B) Concentração de hemoglobina no sangue de $\mathrm{Hb}$ (azul), $\mathrm{HbO}_{2}$ (vermelho) e $\mathrm{HbT}$ (rosa) em unidades arbitrárias (a.u.) numa determinada ROI. C) Saturação média de oxigénio $\left(\mathrm{mSO}_{2}\right)$ acima de 0,7 em todos os voluntários em repouso. 
$\mathrm{Hb}$ signals, the MSOTview is able to calculate the total haemoglobin $(\mathrm{HbT})$ and the mean oxygen saturation $\left(\mathrm{mSO}_{2}\right)$ (Figure 4E-F) (14).

The MSOT calculated HbT (1.23E-04 $\pm 2.75 \mathrm{E}-06$ a.u) is therefore given by the addition $\mathrm{Hb}$ (of 4.00E-05 $\pm 1.14 \mathrm{E}-06$ ) and $\mathrm{HbO}_{2}$ (of 8.31E-05 $\pm 2.21 \mathrm{E}-06$ ) signal intensities shown in Table 2. Data evaluation plotted in Figure 5A summarizes the scans taken from our six volunteers over a total of ten optoacoustic images in $2 \mathrm{~s}$. Data from $\mathrm{Hb}$ (line in blue) and $\mathrm{HbO}_{2}$ (line in red) consistently match consistently their addition as $\mathrm{HbT}$ (line in pink) over the course of the optoacoustic acquisitions. We also observe that in resting position, $\mathrm{HbO}_{2}$ concentration is statistically higher than $\mathrm{Hb}$ in all volunteers (Figure 5B), and that value of $\mathrm{mSO}_{2}$ is consistently above the 0.7 a.u. oxygen saturation signal input cut-off (Figure 5C).

Our approach is in-line with previously published studies showing that that image acquisition with the MSOT system is extremely intuitive (even in 3D mode). Discrimination of the skin microvasculature stratification into upper and lower skin plexus is visualized on demand in different axis $(\mathrm{X}, \mathrm{Y}, \mathrm{Z})$ at a volume of $15 \mathrm{~mm}^{3}$ (4,14-16). The application of ROI analysis shows high descriptive potential as it enables the MSOT to independently and simultaneously evaluate the blood volume and oxygenation of the different skin plexus with different / multiple selected ROI's. Additionally, MSOT selected pre-set offers the possibility to acquire and unmix (at least) three independent chromophores of interest $\left(\mathrm{Hb}, \mathrm{HbO}_{2}\right.$, and melanin in our study) simultaneously.

In any case, the complete stabilization of the $3 \mathrm{D}$ probe during image acquisition is critical for the acquisition quality and for data analysis, such that the use of a fixed stand to secure the probe is essential.

We recognize that the data processing involved is complex, and requires an experienced operator and analyst. However, the possibilities offered by this new system to bring new perspectives especially to vascular pathophysiology research are immense and can be extended beyond current knowledge. de onda (700 nm, $730 \mathrm{~nm}, 760 \mathrm{~nm}, 800 \mathrm{~nm}, 850 \mathrm{~nm}$, e $900 \mathrm{~nm}$ ) é constante a cada $2 \mathrm{~s}$. A estabilidade dos dados do ROI seleccionado é representada pela linearidade do sinal registado para $\mathrm{HbO}_{2}, \mathrm{Hb}$ desoxigenada e melanina (a.u.) (Figura 4B-D). A partir dos sinais de $\mathrm{HbO}_{2}$ e $\mathrm{Hb}$, o MSOTview é capaz de calcular a hemoglobina total $(\mathrm{HbT})$ e a saturação média de oxigénio $\left(\mathrm{mSO}_{2}\right)$ (Figura $4 \mathrm{E}-\mathrm{F})(14)$.

O HbT calculado pelo MSOT (1.23E-04 $\pm 2.75 \mathrm{E}-06$ a.u) é portanto dado pela adição de $\mathrm{Hb}$ (de $4.00 \mathrm{E}-05 \pm 1.14 \mathrm{E}-06$ ) e $\mathrm{HbO}_{2}$ (de $8.31 \mathrm{E}-05 \pm 2.21 \mathrm{E}-06$ ) cujas intensidades de sinal são mostradas na Tabela 2. A avaliação dos dados presentes na Figura 5A resume os dados dos seis voluntários num total de dez imagens optoacústicas durante $2 \mathrm{~s}$. Os dados de $\mathrm{Hb}$ (linha em azul) e $\mathrm{HbO}_{2}$ (linha em vermelho) correspondem consistentemente à sua adição como HbT (linha em rosa) ao longo das aquisições optoacústicas. Observamos também que em posição de repouso, a concentração de $\mathrm{HbO}_{2}$ é estatisticamente superior a $\mathrm{Hb}$ em todos os voluntários (Figura 5B), e que o valor de $\mathrm{mSO}_{2}$ está consistentemente a atingir acima do limite mínimo de saturação de oxigénio de 0,7 a.u. (Figura 5C).

A nossa abordagem está em linha com estudos previamente publicados que mostram que a aquisição de imagem com o sistema MSOT é extremamente intuitiva (mesmo em modo 3D). A discriminação da estratificação da microvasculatura da pele no plexo superior e inferior da pele é visualizada em direto em diferentes eixos (X, Y, Z) num volume de $15 \mathrm{~mm}^{3}$ (4,1416). A aplicação da análise de ROI mostra um elevado potencial descritivo, pois permite ao MSOT avaliar independentemente o volume de sangue e a oxigenação dos diferentes plexos cutâneos em simultâneo com diferentes/múltiplos ROI seleccionados. Além disso, o MSOT seleccionado oferece a possibilidade de adquirir e distinguir pelo menos três cromóforos independentes $\left(\mathrm{Hb}, \mathrm{HbO}_{2}\right.$, melanina no nosso estudo) em simultâneo.

Em qualquer caso, a estabilização total da sonda 3D durante a aquisição da imagem é fundamental para a qualidade da aquisição e para a análise dos dados, o que significa que a utilização de um suporte fixo para estabilizar a sonda é altamente recomendável.

Reconhecemos que o processamento de dados envolvido é complexo e requer uma experiência consistente por parte do operador. No entanto, as possibilidades oferecidas por este novo sistema em proporcionar novas perspectivas são imensas em especial na investigação vascular e podem ser alargadas para além do conhecimento actual. 


\section{Authors Contributions Statement}

LMR, TG conceptualization and study design; TG, SA experimental implementation; TG, data analysis and data curation; TG, LMR, drafting and reviewing; LMR, supervision and final writing.

\section{Funding}

This research is funded by ALIES and COFAC principal providers of the technology under study, and by Fundação para a Ciência e a Tecnologia (FCT) through the grant UIDB/04567/2020 to CBIOS.

\section{Conflict of Interests}

Editors involved in this manuscripts' authorship had no participation in the review or decision process. All authors have stated that there are no financial and/or personal relationships that could represent a potential conflict of interest.

\section{Acknowledgements}

The authors would like to express their thanks to CBIOS staff for their effort supplying all the necessary help, and to all the participants involved in the study.

\section{Declaração sobre as contribuições do autor}

LMR, TG, conceção e desenho do estudo; TG, SA implementação experimental; TG, análise e curadoria de dados; TG, LMR, redacção e revisão; LMR, supervisão e redação final.

\section{Financiamento}

Esta investigação é financiada pela ALIES e pela COFAC principais provedores da tecnologia em estudo, e pela Fundação para a Ciência e a Tecnologia (FCT) através da bolsa UIDB/04567/2020 à CBIOS.

\section{Conflito de Interesses}

Os editores envolvidos na autoria destes manuscritos não tiveram qualquer participação no processo de revisão ou decisão. Todos os autores declararam que não existem relações financeiras e/ou pessoais que possam representar um potencial conflito de interesses.

\section{Agradecimentos}

Os autores gostariam de expressar os seus agradecimentos ao pessoal da CBIOS pelo seu esforço em fornecer toda a ajuda necessária, e a todos os participantes envolvidos no estudo. 


\section{References / Referências}

1. Yodh, A., Chance B. (1995). Spectroscopy and imaging with diffusing light Physics Today 48, 34-40. doi.org/10.1063/1.881445

2. Ntziachristos, V., Ripoll, J., Wang, L. V., \& Weissleder, R. (2005). Looking and listening to light: the evolution of whole-body photonic imaging. Nature biotechnology, 23(3), 313-320. doi.org/10.1038/nbt1074

3. Rubin G. D. (2014). Computed tomography: revolutionizing the practice of medicine for 40 years. Radiology, 273(2 Suppl), S45-S74. doi.org/10.1148/radiol.14141356

4. Karlas, A., Fasoula, N. A., Paul-Yuan, K., Reber, J., Kallmayer, M., Bozhko, D., Seeger, M., Eckstein, H. H., Wildgruber, M., \& Ntziachristos, V. (2019). Cardiovascular optoacoustics: From mice to men - A review. Photoacoustics, 14, 19-30. doi.org/10.1016/j. pacs.2019.03.001

5 Tan, H., Gu, Y., Yu, H., Hu, P., Zhang, Y., Mao, W., \& Shi, H. (2020). Total-Body PET/CT: Current Applications and Future Perspectives. AJR. American journal of roentgenology, 215(2), 325-337. doi.org/10.2214/AJR.19.22705

6. Zhang L, Zhang G. (2019) Brief review on learning-based methods for optical tomography. Journal of Innovative Optical Health Sciences, 12, 1930011. doi: 10.1142/S17935458193001185

7. Hu, S., \& Wang, L. V. (2010). Photoacoustic imaging and characterization of the microvasculature. Journal of biomedical optics, 15(1), 011101. doi.org/10.1117/1.3281673

8. Zhang, H. F., Maslov, K., Stoica, G., \& Wang, L. V. (2006). Functional photoacoustic microscopy for high-resolution and noninvasive in vivo imaging. Nature biotechnology, 24(7), 848-851. doi.org/10.1038/nbt1220

9. Merčep, E., Jeng, G., Morscher, S., Li, P. C., \& Razansky, D. (2015). Hybrid optoacoustic tomography and pulse-echo ultrasonography using concave arrays. IEEE transactions on ultrasonics, ferroelectrics, and frequency control, 62(9), 1651-1661. doi.org/10.1109/ TUFFC.2015.007058

10. Wang L. V. (2009). Multiscale photoacoustic microscopy and computed tomography. Nature photonics, 3(9), 503-509. doi.org/10.1038/ nphoton.2009.157

11. Haedicke, K., Agemy, L., Omar, M., Berezhnoi, A., Roberts, S., Longo-Machado, C., Skubal, M., Nagar, K., Hsu, H. T., Kim, K., Reiner, T., Coleman, J., Ntziachristos, V., Scherz, A., \& Grimm, J. (2020). High-resolution optoacoustic imaging of tissue responses to vasculartargeted therapies. Nature biomedical engineering, 4(3), 286-297. doi.org/10.1038/s41551-020-0527-8

12. Nitkunanantharajah, S., Haedicke, K., Moore, T. B., Manning, J. B., Dinsdale, G., Berks, M., Taylor, C., Dickinson, M. R., Jüstel, D., Ntziachristos, V., Herrick, A. L., \& Murray, A. K. (2020). Three-dimensional optoacoustic imaging of nailfold capillaries in systemic sclerosis and its potential for disease differentiation using deep learning. Scientific reports, 10(1), 16444. https://doi.org/10.1038/ s41598-020-73319-2.

13. Haedicke, K., Brand, C., Omar, M., Ntziachristos, V., Reiner, T., \& Grimm, J. (2017). Sonophore labeled RGD: a targeted contrast agent for optoacoustic imaging. Photoacoustics, 6, 1-8. doi.org/10.1016/j.pacs.2017.03.001.

14. Zafar, H., Breathnach, A., Subhash, H. M., \& Leahy, M. J. (2015). Linear-array-based photoacoustic imaging of human microcirculation with a range of high frequency transducer probes. Journal of biomedical optics, 20(5), 051021. doi.org/10.1117/1.JBO.20.5.051021

15. Yao, J., Xia, J., \& Wang, L. V. (2016). Multiscale Functional and Molecular Photoacoustic Tomography. Ultrasonic imaging, 38(1), 44-62. doi.org/10.1177/0161734615584312

16. Gujrati, V., Mishra, A., \& Ntziachristos, V. (2017). Molecular imaging probes for multi-spectral optoacoustic tomography. Chemical communications (Cambridge, England), 53(34), 4653-4672. https://doi.org/10.1039/c6cc09421j

17. Luís Dean-Ben, X., \& Razansky, D. (2018). Localization optoacoustic tomography. Light, science \& applications, 7, 18004. doi. org/10.1038/1sa.2018.4

18. Karlas, A., Masthoff, M., Kallmayer, M., Helfen, A., Bariotakis, M., Fasoula, N. A., Schäfers, M., Seidensticker, M., Eckstein, H. H., Ntziachristos, V., \& Wildgruber, M. (2021). Multispectral optoacoustic tomography of peripheral arterial disease based on muscle hemoglobin gradients-a pilot clinical study. Annals of translational medicine, 9(1), 36. doi.org/10.21037/atm-20-3321

19. World Medical Association. (2013) World Medical Association Declaration of Helsinki: ethical principles for medical research involving human subjects. JAMA 310(20):2191-2194. doi:10.1001/jama.2013.281053

20. Taruttis, A., Timmermans, A. C., Wouters, P. C., Kacprowicz, M., van Dam, G. M., \& Ntziachristos, V. (2016). Optoacoustic Imaging of Human Vasculature: Feasibility by Using a Handheld Probe. Radiology, 281(1), 256-263. doi.org/10.1148/radiol.2016152160

21. Kneipp, M., Turner, J., Hambauer, S., Krieg, S. M., Lehmberg, J., Lindauer, U., \& Razansky, D. (2014). Functional real-time optoacoustic imaging of middle cerebral artery occlusion in mice. PloS one, 9(4), e96118. doi.org/10.1371/journal.pone.0096118

22. van den Berg, P. J., Daoudi, K., \& Steenbergen, W. (2015). Review of photoacoustic flow imaging: its current state and its promises. Photoacoustics, 3(3), 89-99. doi.org/10.1016/j.pacs.2015.08.001 